\title{
Obtaining Antioxidants and Natural Preservatives from Food By-Products through Fermentation: A Review
}

\author{
Francisco J. Martí-Quijal ${ }^{1}\left(\right.$ , Sucheta Khubber ${ }^{2}$, Fabienne Remize ${ }^{3}{ }^{\circledR}$, Igor Tomasevic ${ }^{4}{ }^{\circledR}$, Elena Roselló-Soto ${ }^{1, *}$ \\ and Francisco J. Barba ${ }^{1}$ (D) \\ 1 Department of Preventive Medicine and Public Health, Food Sciences, Toxicology and Forensic Medicine, \\ Faculty of Pharmacy, Universitat de València, Avda. Vicent Andrés Estellés, s/n, \\ 46100 Burjassot, València, Spain; francisco.j.marti@uv.es (F.J.M.-Q.); francisco.barba@uv.es (F.J.B.) \\ 2 Food Engineering and Nutrition, Center of Innovative and Applied Bioprocessing, Mohali 140306, India; \\ suchetakkr@gmail.com \\ 3 SPO, Univ La Réunion, Univ Montpellier, INRAE, Institut Agro, 34060 Montpellier, France; \\ fabienne.remize@univ-reunion.fr \\ 4 Faculty of Agriculture, University of Belgrade, 11080 Belgrade, Serbia; tbigor@agrif.bg.ac.rs \\ * Correspondence: eroso2@alumni.uv.es
}

check for

updates

Citation: Martí-Quijal, F.J.; Khubber,

S.; Remize, F.; Tomasevic, I.;

Roselló-Soto, E.; Barba, F.J. Obtaining

Antioxidants and Natural

Preservatives from Food By-Products through Fermentation: A Review.

Fermentation 2021, 7, 106. https://

doi.org/10.3390/fermentation7030106

Academic Editors: Annalisa Serio and Clemencia Chaves-López

Received: 28 April 2021

Accepted: 2 July 2021

Published: 7 July 2021

Publisher's Note: MDPI stays neutral with regard to jurisdictional claims in published maps and institutional affiliations.

Copyright: (c) 2021 by the authors. Licensee MDPI, Basel, Switzerland. This article is an open access article distributed under the terms and conditions of the Creative Commons Attribution (CC BY) license (https:/ / creativecommons.org/licenses/by/ $4.0 /)$.
Abstract: Industrial food waste has potential for generating income from high-added-value compounds through fermentation. Solid-state fermentation is promising to obtain a high yield of bioactive compounds while requiring less water for the microorganism's growth. A number of scientific studies evinced an increase in flavonoids or phenolics from fruit or vegetable waste and bioactive peptides from cereal processing residues and whey, a major waste of the dairy industry. Livestock, fish, or shellfish processing by-products (skin, viscera, fish scales, seabass colon, shrimp waste) also has the possibility of generating antioxidant peptides, hydrolysates, or compounds through fermentation. These bioactive compounds (phenolics, flavonoids, or antioxidant peptides) resulting from bacterial or fungal fermentation are also capable of inhibiting the growth of commonly occurring food spoilage fungi and can be used as natural preservatives. Despite the significant release or enhancement of antioxidant compounds through by-products fermentation, the surface areas of large-scale bioreactors and flow patterns act as constraints in designing a scale-up process for improved efficiency. An inprocess purification method can also be the most significant contributing factor for raising the overall cost. Therefore, future research in modelling scale-up design can contribute towards mitigating the discard of high-added-value generating residues. Therefore, in this review, the current knowledge on the use of fermentation to obtain bioactive compounds from food by-products, emphasizing their use as natural preservatives, was evaluated.

Keywords: fermentation; food by-products; antioxidant; antifungal

\section{Introduction}

The processing of food by the industry generates a large amount of by-products that are generally discarded. In some cases, these by-products are reused for animal feed or as fuel for energy, but they still have a low economic value. It has been estimated that 88 million tons of by-products are generated from the agri-food industry, at a cost of 143,000 million euros [1]. These by-products can be converted into a wide variety of compounds with high added value, such as biofuels or bioactive compounds [2].

Fermentation has been used for thousands of years to preserve food or produce compounds of interest such as ethanol. Over time, this process has been gaining importance in research related to nutrition and health, because through fermentation, bioactive compounds of interest are obtained, such as antioxidant compounds [3]. It also raises interest at an industrial level since it allows the reuse of waste to obtain the desired compounds from them. In this way, it contributes to protecting the environment by reducing the environmental impact caused by these wastes [4]. 
Finally, societal demand increasingly tends toward foods with additives of natural origin and the avoidance of those of chemical origin. An important part of the compounds added to a food are preservatives, since they allow the extension of its shelf-life and reduces economic losses. Therefore, through fermentation, natural compounds can be obtained to replace the chemical products currently used for this purpose. Thus, the present review aimed to evaluate the current knowledge on the use of fermentation to obtain bioactive compounds from food by-products, emphasizing their use as natural preservatives.

\section{Fermentation Processes}

Although fermentation has been used since ancient times, techniques have been improved to increase productivity, developing increasingly efficient processes. Currently, to carry out the fermentation process, two different strategies are usually used depending on the type of substrate: submerged fermentation or solid-state fermentation. The first process is submerged fermentation $(\mathrm{SmF})$. To perform this, a liquid substrate can be used or water can be added to a solid substrate (Figure 1).

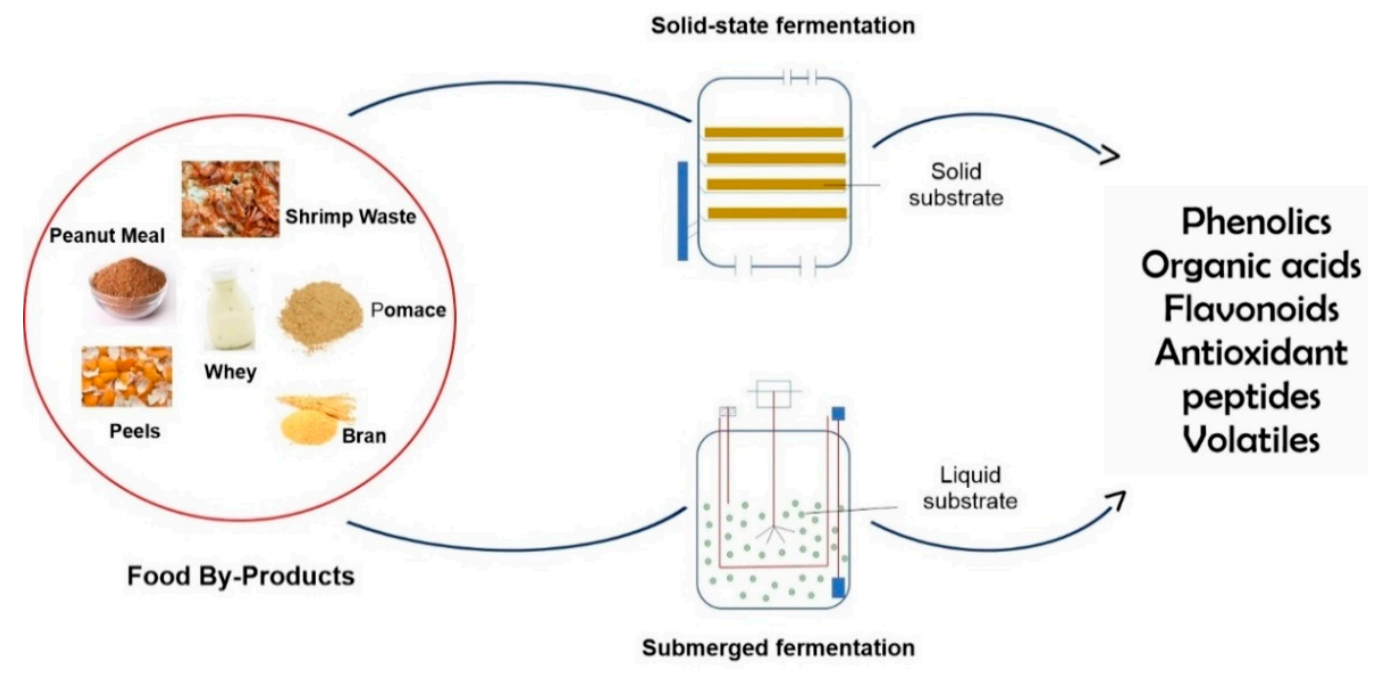

Figure 1. Overview of food by-product fermentation to produce antioxidant compounds or natural preservatives.

This fermentation method is the one chosen when bacteria or yeasts are used to ferment, since they need high humidity [5]. The bioactive compounds produced by microorganisms during fermentation are secreted into the liquid medium. Therefore, SmF is commonly used for the production of secondary metabolites in the liquid state [6]. Among its main advantages we can highlight the production of compounds on a large scale, a good transfer of mass and heat during the process, and a better diffusion of microorganisms. However, its drawbacks are low performance, high energy consumption, and that it is not environmentally friendly due to the high volume of waste water that is generated [5].

Although SmF is not the most widely used technique for the reuse of food by-products, some authors have explored its use to obtain bioactive compounds (Table 1). In this sense, Zhang et al. [7] used shrimp by-products as substrate to obtain chitin and chitosan using SmF. Mucor sp. strains produced gamma-linolenic acid and beta-carotene after SmF fermentation of agro-industrial waste (brans, spent malt grains, distiller grains, etc.) [8]. On the other hand, Bartkiene et al. [9] used SmF to obtain different antioxidant and antimicrobial compounds by fermenting barley by-products with the bacterium Pediococcus acidilactici. In addition, Zou et al. [10] also used SmF to enhance antioxidant activity of ginkgo seeds suspension through fermentation with Eurotium cristatum. Finally, agri-food waste cannot only serve as a substrate, but also as a support for fermentation. In this sense, Das et al. [11] used the eggshell as a support for the fermentation of wastewater from a brewery with the Rhizopus oryzae fungus, obtaining fumaric acid. 
Table 1. Antioxidant and antifungal compounds obtained from food processing by-products.

\begin{tabular}{|c|c|c|c|c|}
\hline $\begin{array}{l}\text { Food By-Product } \\
\text { (Substrate) }\end{array}$ & Microorganism & Fermentation & Compounds Obtained & Reference \\
\hline Pomelo peels & F33 activated yeast & $\mathrm{SmF}$ & Flavonoids & {$[12]$} \\
\hline Grapefruit by-products & Aspergillus niger & SSF & Antioxidant compounds & [13] \\
\hline Hass avocado seeds & A. niger $\mathrm{GH} 1$ & SSF & Phenolic compounds & {$[14]$} \\
\hline $\begin{array}{l}\text { Plum by-products } \\
\text { (pomaces, spent fruit pulp } \\
\text { and peels) }\end{array}$ & A. niger and Rhizopus oligosporus & SSF & $\begin{array}{l}\text { Phenolic compounds } \\
\text { (mainly isoquercitrin, cinnamic } \\
\text { acids and rutin) and flavonoids }\end{array}$ & {$[15]$} \\
\hline Chokeberry pomace & A. niger and R. oligosporus & SSF & Polyphenols and flavonoids & [16] \\
\hline $\begin{array}{l}\text { Grape, apple and pitahaya } \\
\text { by-products }\end{array}$ & Rhizomucor miehei NRRL5282 & SSF & Phenolic compounds & [17] \\
\hline Grape pomace & $\begin{array}{l}\text { Actinomucor elegans and } \\
\text { Umbelopsis isabellina }\end{array}$ & SSF & $\begin{array}{c}\gamma \text {-linolenic acid, carotenoids, } \\
\text { phenolic compounds } \\
\text { and flavonoids }\end{array}$ & {$[18]$} \\
\hline Wheat and oat bran & Saccharomyces cerevisiae & SSF & Polyphenols & [19] \\
\hline Peanut meal & Bacillus subtilis & $\mathrm{SmF}$ & Antioxidant peptides & {$[20]$} \\
\hline Peanut press cake & Aspergillus awamori & SSF & Phenols and flavonoids & [21] \\
\hline Brewer's spent grain & $\begin{array}{c}\text { A. awamori, Aspergillus oryzae, } \\
\text { Aspergillus terreus, A. niger and R. oryzae }\end{array}$ & SSF & $\begin{array}{l}\text { Phenolic compounds } \\
\text { (mainly ferulic, p-coumaric and } \\
\text { caffeic acids) }\end{array}$ & {$[22]$} \\
\hline Barley bran & A. oryzae & SSF & Phenolic compounds & {$[23]$} \\
\hline Wheat bran & Enterococcus faecalis $M 2$ & SSF & $\begin{array}{l}\text { Phenols, flavonoids } \\
\text { and alkylresorcinols }\end{array}$ & {$[24]$} \\
\hline $\begin{array}{l}\text { Rice starch extraction } \\
\text { by-product }\end{array}$ & Bacillus spp. & $\mathrm{SmF}$ & Antioxidant peptides & {$[25]$} \\
\hline Whey proteins & Bacillus subtilis & $\mathrm{SmF}$ & Antioxidant peptides & [26] \\
\hline $\begin{array}{c}\text { Whey } \\
\text { (cheese manufacturing } \\
\text { by-product) }\end{array}$ & Bacillus clausii & $\mathrm{SmF}$ & Antioxidant peptides & {$[27]$} \\
\hline Camel milk whey & Lactobacillus delbrueckii subsp. lactis & $\mathrm{SmF}$ & Antioxidant peptides & {$[28]$} \\
\hline Porcine liver proteins & Monascus purpureus & $\mathrm{SmF}$ & Antioxidant peptides & {$[29]$} \\
\hline $\begin{array}{l}\text { Chicken eggshell } \\
\text { membrane }\end{array}$ & Lactiplantibacillus plantarum & $\mathrm{SmF}$ & Antioxidant peptides & {$[30]$} \\
\hline Sea bass by-products & L. plantarum & $\mathrm{SmF}$ & Antioxidant compounds & {$[31]$} \\
\hline Turbot skin & A. oryzae & $\mathrm{SmF}$ & Antioxidant peptides & {$[32]$} \\
\hline Carp heads & $\begin{array}{l}\text { Pediococcus acidilactici and } \\
\text { Enterococcus faecium }\end{array}$ & $\mathrm{SmF}$ & $\begin{array}{l}\text { Antioxidant and } \\
\text { antifungal peptides }\end{array}$ & {$[33]$} \\
\hline $\begin{array}{l}\text { Fermented fish sauce } \\
\text { by-product }\end{array}$ & - & $\mathrm{SmF}$ & Antioxidant peptides & {$[34]$} \\
\hline $\begin{array}{c}\text { Shrimp waste } \\
\text { (cephalothoraxes and } \\
\text { carapaces) }\end{array}$ & Bacillus cereus & SSF & Antioxidant chitooligosaccharides & {$[35]$} \\
\hline Shrimp waste & P. acidolactici & $\mathrm{SmF}$ & Antioxidant compounds & [36] \\
\hline Rice bran & R. oryzae & $\mathrm{SmF}$ & Phenolic compounds & {$[37]$} \\
\hline Rice bran & R. oryzae & $\mathrm{SmF}$ & Phenolic compounds & {$[38]$} \\
\hline Apple by-products & Weissella cibaria and S. cerevisiae & $\mathrm{SmF}$ & $\begin{array}{c}\text { Dietary fibers and } \\
\text { volatile compounds }\end{array}$ & {$[39]$} \\
\hline $\begin{array}{c}\text { Whey } \\
\text { (cheese manufacturing } \\
\text { by-product) }\end{array}$ & L. plantarum & $\mathrm{SmF}$ & Antifungal compounds & {$[40]$} \\
\hline $\begin{array}{c}\text { Whey } \\
\text { (cheese manufacturing } \\
\text { by-product) }\end{array}$ & L. plantarum & $\mathrm{SmF}$ & Antifungal compounds & {$[41]$} \\
\hline Sea bass by-products & L. plantarum & $\mathrm{SmF}$ & Antifungal compounds & {$[42]$} \\
\hline Shrimp and crab shell & B. cereus & $\mathrm{SmF}$ & Antifungal compounds & {$[43]$} \\
\hline
\end{tabular}

\footnotetext{
"-": microorganisms were not reported in the article. SmF: Submerged Fermentation; SSF: Solid-State Fermentation.
} 
The other fermentation process is known as solid-state fermentation (SSF). In this case, a solid substrate is used in the absence of water and the fermentating microorganisms grow on it [44]. For this fermentation technique, microorganisms that do not require a high water level in the medium are used, such as fungi [6]. With this method, the nutrients in the solid substrate are used to the maximum. The advantages of SSF over SmF are a high yield, obtaining a final product with high activity, low water consumption, being more environmentally friendly, and greater resistance to contamination. Another advantage of this method is the possibility of using agricultural by-products as substrate for fermentation, allowing the recovery of compounds of biological interest and reducing the waste generated. Through this process, products of high economic value can be obtained. The main drawbacks are the difficulty to scale-up the process, the accumulation of heat, and the difficulty to correctly control the process parameters [5]. In fact, the main compounds produced from agricultural by-products by SSF are enzymes [45]. Agricultural residues contain all the necessary nutrients for the good growth of the microorganisms used for fermentation; therefore, a very good process performance is obtained. Some of the most commonly used by-products in this process are molasses, pomace, bagasse, roots, seeds, husks, peels, stems, stalks, and leaves [46]. Therefore, SSF is considered a promising and ecological process with significant future prospects for obtaining compounds of interest [47].

Several authors have investigated the use of this process to obtain different bioactive compounds from agro-industrial by-products. SSF is very useful to that aim, since through the action of bacterial enzymes the hydrolysis of the cell walls is achieved, releasing different compounds such as polyphenols, vitamins, organic acids, or bioactive peptides [48]. In this sense, Fang et al. [49] used SSF to obtain poly- $\gamma$-glutamic acid with Bacillus amyloliquefaciens and a natural complex microbial community from corn stalk and soybean meal. One of its main uses is to obtain antioxidant compounds, although it can also be used for other compounds of interest in the food industry, such as antifungals (Table 1). Lastly, food by-products can be also used to obtain different enzymes, which are used later to obtain bioactive compounds. In this sense, Teles et al. [50] used grape pomace and wheat bran as a substrate for the production of several hydrolytic enzymes through fermentation with Aspergillus niger, which were later applied to grape pomace to recover polyphenols.

\section{Preservative Compounds Obtained from Food By-Products Fermentation}

\subsection{Antioxidants}

As mentioned above, some of the main products obtained after fermentation are antioxidant compounds. Antioxidant compounds are interesting from a health point of view, since, as it is known, oxidative stress is related to a wide variety of diseases such as cancer, cardiovascular diseases, diabetes, and neurodegenerative diseases [51]. However, these compounds are also interesting for industry, specifically the food industry, since they can be used as natural preservatives in processed foods to prevent their oxidation [52]. The main antioxidant compounds obtained from plant matrices are phenolic compounds, like phenolic acids or flavonoids, which have a remarkable antioxidant activity. Moreover, other vegetal compounds such as carotenoids or vitamins are also important antioxidants [53]. Fermentation processes can increase the extraction of antioxidant molecules from food matrices, including vegetable by-products. Moreover, fermentation can also modify the profile and types of antioxidant bioactive compounds, or even produce new compounds with biological activities of interest. Fermentation can also act on the activity of the compounds or on their bioaccessibility/bioavailability [54-58]. Bioaccessibility is primarily modulated during fermentation by deaggregation and deglycosylation of phenolic compounds or carotenoids and even by the release of monomeric phenolic compounds, or by isomerization as in the case for lycopene. However, the bioavailability of dietary polyphenols in the human body remains unclear. Extensive glycosylation of these compounds causes a poor intestinal absorption. Hence, increased bioaccessibility resulting from fermentation is seen as a positive factor for bioavailability, which depends on numerous 
factors related to diet composition and also relies on the metabolic activity of large intestine microbiota able to release aglycones.

Regarding animal by-products, the main source of antioxidant compounds are bioactive peptides, originated after the fermentation process, or a chemical or enzymatic hydrolysis of proteins. Finally, fermentation processes can also release antioxidant compounds which were not present before, like exopolysaccharides, which are produced by microorganisms using sugars as substrate [59].

The main substrates used to obtain antioxidant compounds come from by-products of plant matrices. The industrial processing of fruits and vegetables generate by-products such as skin, peel, pomace, and seeds, which represent around $30 \%$ of the weight of the product. These by-products are rich in bioactive compounds such as vitamins, pigments (chlorophylls, carotenoids, lycopene, etc.), flavonoids, and phenolic compounds, as well as containing dietary fibers. This, together with the presence of water in these by-products, makes them a perfect substrate to carry out SSF (Figure 2), as can be seen in the existing literature. In this sense, Tian et al. [12] observed an increase in the presence of flavonoids after fermentation of grapefruit peels with F33 activated yeast. Larios-Cruz et al. [13] also observed that grapefruit by-products could be used as a source of antioxidant compounds after fermentation with $A$. niger. Yepes-Betancur et al. [14] used SSF to ferment hass avocado seed with $A$. niger GH1 to release bioactive compounds with antioxidant capacity. They reported an increase in antioxidant activity measured by DPPH and ABTS due to the release of phenolic compounds by the activities of the enzymes cellulase and xylanase. Dulf et al. [15] also used generally recognized as safe (GRAS) fungi, specifically A. niger and Rhizopus oligosporus, to ferment different plum by-products (pomaces, spent fruit pulp, and peels). These authors reported an increase in phenolic compounds (mainly isoquercitrin, cinnamic acids, and rutin) and flavonoids after the fermentation process, which was correlated with an increase in the antioxidant capacity of the fermented samples. In another study, Dulf et al. [16] also reported an increase in the extraction of polyphenols and flavonoids after the fermentation of chokeberry pomace with $A$. niger and R. oligosporus, improving antioxidant activity. Zambrano et al. [17] fermented grape, apple, and pitahaya by-products with Rhizomucor miehei NRRL5282, increasing the recovery of polyphenolic compounds and antioxidant activity (measured by DPPH and FRAP). Lastly, the production of other compounds such as carotenoids has been also explored. In this sense, Dulf et al. [18] used Actinomucor elegans and Umbelopsis isabellina to obtain higher production of $\gamma$-linolenic acid and carotenoids, like lutein or $\beta$-carotene, from grape pomace. Moreover, the fermentation of this by-product with A. elegans increased the total flavonoid and phenolic content, and then improved antioxidant activity.

On the other hand, by-products from industrial cereal processing also represent an inexpensive and abundant source of bioactive compounds. Regarding this, Călinoiu et al. [19] studied the fermentation of wheat and oat bran by Saccharomyces cerevisiae using solid-state yeast fermentation. They found the highest levels of total polyphenols after $3(0.84 \pm 0.05 \mathrm{mg}$ of gallic acid equivalents (GAE)/g dry weight (DW)) and $4(0.45 \pm 0.02 \mathrm{mg}$ GAE/g DW) days of fermentation for wheat and oat bran, respectively. Sadh et al. [21] reported an increase in antioxidant compounds such as phenols and flavonoids when fermenting peanut press cake with Aspergillus awamori. Da Costa Maia et al. [22] applied SSF to brewer's spent grain, using several fungi strains to increase the recovery of phenolic compounds. The most effective fungus was Aspergillus oryzae, and the main extracted polyphenols were ferulic, p-coumaric, and caffeic acids. Bangar et al. [23] also used A. oryzae to ferment barley bran, showing after fermentation a significant increase in phenolic compounds, specially gallic acid (from 12.75 to $405.5 \mu \mathrm{g} / \mathrm{g}$ ), catechin (from 9.9 to $88.3 \mu \mathrm{g} / \mathrm{g}$ ), and scorbic acid (from 20.44 to $107.15 \mu \mathrm{g} / \mathrm{g}$ ), among others. As a result, antioxidant activity was enhanced significantly. Wheat bran was fermented by Mao et al. with Enterococcus faecalis M2, increasing the total phenolic compounds, flavonoids, and antioxidant capacity significantly. These authors reported an increase of gallic acid (1.5-fold), p-coumaric acid (1.4-fold), ferulic acid (2.6-fold), and cinnamic acid (1.4-fold) after the fermentation pro- 
cess compared with raw wheat bran content [24]. Lactic acid bacteria (LAB) are known to be capable of producing bioactive peptides after fermentation of high-protein plant by-products. It has been observed that after fermenting peanut meal with Bacillus subtilis, peptides with an antioxidant capacity of $63.28 \%$ were obtained, in comparison with BHT, whose antioxidant activity was $99.16 \%$ [20]. It has also been seen that after fermentation of rice starch extraction by-product with Bacillus spp., bioactive peptides with antioxidant activity are obtained [25].
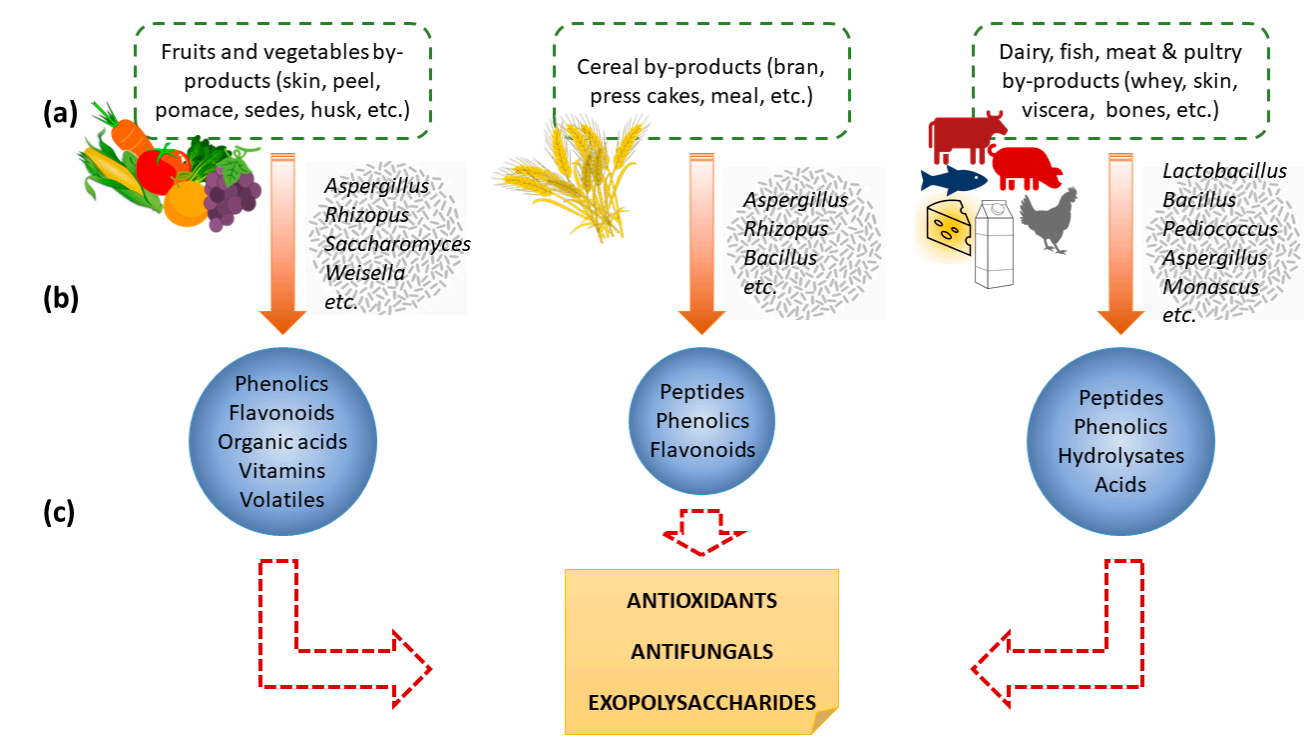

Figure 2. Flow-chart for antioxidants, antifungals, and exopolysaccharides from food by-products sources using fermentation: (a) categories of food by-products; (b) major microbes involved in fermentation; (c) fermentative microbial metabolites acting as antifungals or antioxidants.

Another food by-product with great nutritional value is whey, which is estimated to contain around $55 \%$ of the nutrients originally present in milk and can represent $90 \%$ of the weight of the milk used to make cheese. Through fermentation, bioactive compounds of interest with antioxidant capacity can be obtained [60] (Figure 2). The compounds obtained, as well as their antioxidant activity, vary depending on the substrate and the microorganism used for fermentation [61]. Among the compounds obtained, we can highlight lactobionic acid, which has antioxidant capacity, or exopolysaccharides, some of which also have antioxidant properties [62,63]. Production of exopolysaccharides by LAB, especially Leuconostoc pseudomesenteroides, Leuconostoc mesenteroides, or Weissella cibaria, can reach several tens of $\mathrm{g} / \mathrm{L}$ [64].

Bioactive peptides with antioxidant activity derived from whey proteins can also be obtained. An example is the study carried out by Alvarado Perez et al. [26], in which whey proteins were fermented with Bacillus subtilis, obtaining peptides less than $3 \mathrm{kDa}$ which had significant antioxidant capacity. Rochín-Medina et al. [27] used the whey resulting from the manufacture of cheese as a substrate for the growth of the bacterium Bacillus clausii. They reported the generation of peptides with antioxidant activity capable of inhibiting the ABTS and DPPH radicals by $95 \%$ and $80 \%$, respectively. Finally, Gammoh et al. [28] reported an increase in antioxidant activity after fermenting camel milk whey with Lactobacillus delbrueckii subsp. lactis.

Finally, by-products from animal origin, coming from the livestock and fishery industries, are also good substrates. Due to the high protein content of these by-products, the use of fermentation allows the release of bioactive peptides.

Regarding meat by-products, Yu et al. [29] fermented porcine liver proteins with Monascus purpureus. They reported a high antioxidant capacity of the obtained hydrolysate, even more than those obtained with enzymes. However, there are not many more studies 
related to obtaining bioactive peptides with antioxidant activity from by-products of the meat industry, so future research in this regard would be interesting [63].

Another by-product of animal origin is the eggshell. It represents $11 \%$ of the total weight of the egg, and contains essential nutrients for microorganisms, such as $\mathrm{Fe}$, $\mathrm{Mg}, \mathrm{Zn}$, and $\mathrm{Ca}^{2+}[65,66]$. Jai and Anal [30] fermented chicken eggshell membrane with Lactiplantibacillus plantarum, obtaining a hydrolyzate with significant antioxidant power (70.5\% inhibition of the DPPH radical).

Finally, the fishing industry and aquaculture also generate a large quantity of byproducts, representing a great environmental and economic problem. Therefore, revaluing these by-products would help to make the fish industry more ecological, sustainable, and efficient. Fish waste usually includes the head, skin, viscera, bones, and scales, and they represent around $60 \%$ of the total weight of the product [67]. On the other hand, shellfish by-products are mainly the exoskeleton, shells, and heads, and represent $75 \%$ of the product weight.

Regarding fish by-products, Marti-Quijal et al. [31] reported high antioxidant activity after fermentation of fish by-products broth by L. plantarum isolated from sea bass colon (6.502 $\mathrm{mM}$ Trolox equivalents (TE)) and stomach (4.797 mM TE). The main antioxidant compounds obtained from the fermentation process of fish by-products are bioactive peptides with antioxidant capacity. In this sense, Fang et al. [32] fermented discarded turbot skin with $A$. oryzae to obtain bioactive antioxidant peptides. Ruthu et al. [33] also obtained protein hydrolysates with high antioxidant capacity by fermenting carp heads with P. acidilactici and Enterococcus faecium. Finally, Choksawangkarn et al. [34] found antioxidant peptides in fermented fish sauce by-product.

On the other hand, concerning shellfish by-products, we can highlight the production of antioxidant chitooligosaccharides when shrimp waste (cephalothoraxes and carapaces) was fermented. The chitooligosaccharides obtained had an antioxidant activity of $55.89 \mu \mathrm{g}$ TE/mg measured by DPPH assay [35]. Sachindra and Bhaskar [36] also obtained compounds with antioxidant activity by fermenting shrimp waste with P. acidolactici. The extracts obtained showed strong radical scavenging of ABTS and DPPH radicals. At a concentration of $0.5 \mathrm{mg} / \mathrm{mL}$, ABTS radical scavenging was $95 \%$, while at a concentration of $1 \mathrm{mg} / \mathrm{mL}$ DPPH radical scavenging was $40 \%$.

\subsection{Antifungals}

Antifungals are another group of useful compounds for the preservation of food, since they prevent its contamination by fungi and therefore extend its shelf-life. Fungal contamination produces changes in food. These changes can be visual alterations, the smell or taste of the food can be altered, or toxins that are harmful to the health of the consumer can be produced. The use of antifungal compounds is necessary to prevent the spoilage of food and the economic losses that this entails. Currently, some fungicides of chemical origin are used, which can lead to both environmental and health problems [68]. Therefore, it is necessary to search for antifungal compounds of natural origin that avoid these problems and are more sustainable.

Currently, the main antifungal compounds of natural origin are essential oils and the use of microorganisms as preservatives, either through fermentation or through the use of their metabolites [68]. In this context, the fermentation of food by-products to obtain antifungal compounds creates a significant opportunity to reduce environmental impact and revalue these wastes. The nature of antifungal compounds is diverse: organic and fatty acids, peptides, volatiles, and even enzymes.

Christ-Ribeiro et al. [37] reported a positive correlation between antifungal properties and phenolic compounds. After fermenting rice bran with $R$. oryzae, these authors found a $39.8 \%$ inhibition of the fungal growth of Penicillium verrucosum, related to the polyphenol content of the fermented sample. This is consistent with that described by Denardi-Souza et al. [38], who also fermented rice bran with R. oryzae, obtaining an extract rich in phenolic compounds. This extract was tested against fungi of the genera Aspergillus, Penicillium, 
and Fusarium, obtaining values for the minimum inhibitory concentration (MIC) from 390 to $3100 \mu \mathrm{g} / \mathrm{mL}$, and for the minimum fungicidal concentration (MFC) from 780 to $6300 \mu \mathrm{g} / \mathrm{mL}$. The authors also reported that the most sensitive fungi to the phenolic extracts were $A$. niger, Penicillium roqueforti, Penicillium expansum, Fusarium graminearum, Fusarium culmorum, and Fusarium poae. These extracts were tested on bread, resulting in a three-day increase in the half-life of the bread. Cantatore et al. [39] fermented apple byproducts with a binary mixture of $W$. cibaria and $S$. cerevisiae for $48 \mathrm{~h}$. It was observed that by including the fermented extract in the breadmaking, mold contamination was delayed.

On the other hand, antifungal compounds have also been obtained after the fermentation of by-products of the dairy industry. In this sense, we can highlight the study carried out by Izzo et al. [40], in which L. plantarum fermented whey was used for the production of pita bread, obtaining a complete reduction in contamination by fungi when the water was completely replaced by fermented whey during the process of elaboration. In another study, Luz et al. [41] used fermented whey to prevent the growth of P. expansum in sliced bread. After the application of the treatment, an inactivation of 0.5-0.6 log CFU/g was achieved.

Compounds with antifungal activity have also been obtained from animal by-products. In this sense, Marti-Quijal et al. [42] fermented sea bass by-products with Lactobacillus plantarum, obtaining extracts with antifungal activity against fungi of the Aspergillus, Penicillium, and Fusarium genera. The values obtained from MIC and MFC ranged from 1 to $32 \mathrm{~g} / \mathrm{L}$ and from 8 to $32 \mathrm{~g} / \mathrm{L}$, respectively. The main inhibited fungi were Aspergillus parasiticus, P. expansum and Fusarium verticillioides. Ruthu et al. [33] fermented Indian major carp (Rohu and Catla) heads with E. faecium and P. acidilactici. When applying the hydrolysates obtained as antifungal agents, they obtained a MIC of $60 \mathrm{mg} / \mathrm{mL}$ against Aspergillus ochraceus and $96 \mathrm{mg} / \mathrm{mL}$ against Penicillium chrysogenum.

Lastly, antifungal compounds have also been obtained by fermenting shellfish byproducts. Chang et al. [43] fermented shrimp and crab shell powder with the bacteria Bacillus cereus. The extract obtained showed antifungal activity against Fusarium oxysporum, Fusarium solani, and Pythium ultimum by inhibiting spore germination and germ tube elongation.

\section{Conclusions}

As was observed, fermentation is a useful tool for obtaining antioxidant and antifungal compounds. In addition, by-products from the food industry can be used for this process, making the process more sustainable, giving an added value to these by-products, and reducing their environmental impact. Regarding the fermentation process, it was observed that SSF is the best due to its high yield and low cost. However, more research focused on the scaling process is still necessary to take advantage of all the knowledge acquired in the laboratory and to put it into practice at an industrial level.

Author Contributions: F.J.M.-Q., S.K. and F.J.B. conceived the review; F.J.M.-Q., S.K. and F.J.B. wrote the manuscript; F.R., I.T., F.J.B. and E.R.-S. supervised the study and reviewed the manuscript. All authors have read and agreed to the published version of the manuscript.

Funding: This research received no external funding.

Acknowledgments: F.J.M.-Q. would like to thank the pre-PhD scholarship program of University of Valencia "Atracció de Talent". Moreover, F.J.M-Q. and F.J.B. would like to acknowledge the EU Commission for the support provided by the BBI-JU through the H2020 Project AQUABIOPROFIT 'Aquaculture and agriculture biomass side stream proteins and bioactives for feed, fitness and health promoting nutritional supplements' (Grant Agreement No. 790956).

Conflicts of Interest: The authors declare no conflict of interest. 


\section{References}

1. Stenmarck, Å.; Jensen, C.; Quested, T.; Moates, G. Estimates of European Food Waste Levels; European Commission: Brussels, Belgium, 2016.

2. Ng, H.S.; Kee, P.E.; Yim, H.S.; Chen, P.T.; Wei, Y.H.; Chi-Wei Lan, J. Recent advances on the sustainable approaches for conversion and reutilization of food wastes to valuable bioproducts. Bioresour. Technol. 2020, 302, 12288. [CrossRef]

3. Hur, S.J.; Lee, S.Y.; Kim, Y.C.; Choi, I.; Kim, G.B. Effect of fermentation on the antioxidant activity in plant-based foods. Food Chem. 2014, 160, 346-356. [CrossRef]

4. Martins, S.; Mussatto, S.I.; Martínez-Avila, G.; Montañez-Saenz, J.; Aguilar, C.N.; Teixeira, J.A. Bioactive phenolic compounds: Production and extraction by solid-state fermentation. A review. Biotechnol. Adv. 2011, 29, 365-373. [CrossRef] [PubMed]

5. Doriya, K.; Jose, N.; Gowda, M.; Kumar, D.S. Solid-state fermentation vs submerged fermentation for the production of L-Asparaginase. In Advances in Food and Nutrition Research; Academic Press: Cambridge, MA, USA, 2016; Volume 78, pp. 115-135.

6. Subramaniyam, R.; Vimala, R. Solid state and submerged fermentation for the production of bioactive substances: A comparative study. Int. J. Sci. Nat. 2012, 3, 480-486.

7. Zhang, H.; Yun, S.; Song, L.; Zhang, Y.; Zhao, Y. The preparation and characterization of chitin and chitosan under large-scale submerged fermentation level using shrimp by-products as substrate. Int. J. Biol. Macromol. 2017, 96, 334-339. [CrossRef]

8. Klempová, T.; Slaný, O.; Michal, Š.; Marcin, S.; Milan, Č. Dual production of polyunsaturated fatty acids and beta-carotene with Mucor wosnessenskii by the process of solid-state fermentation using agro-industrial waste. J. Biotechnol. 2020, $311,1-11$. [CrossRef] [PubMed]

9. Bartkiene, E.; Mozuriene, E.; Lele, V.; Zokaityte, E.; Gruzauskas, R.; Jakobsone, I.; Juodeikiene, G.; Ruibys, R.; Bartkevics, V. Changes of bioactive compounds in barley industry by-products during submerged and solid-state fermentation with antimicrobial Pediococcus acidilactici strain LUHS29. Food Sci. Nutr. 2019, 8, 340-350. [CrossRef]

10. Zou, M.; Zhang, W.; Dong, Q.; Tang, C.; Cao, F.; Su, E. Submerged fermentation of Ginkgo biloba seed powder using Eurotium cristatum for the development of ginkgo seeds fermented products. J. Sci. Food Agric. 2021, 101, 1782-1791. [CrossRef]

11. Das, R.K.; Brar, S.K.; Verma, M. Valorization of egg shell biowaste and brewery wastewater for the enhanced production of fumaric acid. Waste Biomass Valorization 2015, 6, 535-546. [CrossRef]

12. Tian, X.; Liu, Y.; Feng, X.; Khaskheli, A.A.; Xiang, Y.; Huang, W. The effects of alcohol fermentation on the extraction of antioxidant compounds and flavonoids of pomelo peel. LWT Food Sci. Technol. 2017, 89, 763-769. [CrossRef]

13. Larios-Cruz, R.; Buenrostro-Figueroa, J.; Prado-Barragán, A.; Rodríguez-Jasso, R.M.; Rodríguez-Herrera, R.; Montañez, J.C.; Aguilar, C.N. Valorization of grapefruit by-products as solid support for solid-state fermentation to produce antioxidant bioactive extracts. Waste Biomass Valorization 2019, 10, 763-769. [CrossRef]

14. Yepes-Betancur, D.P.; Márquez-Cardozo, C.J.; Cadena-Chamorro, E.M.; Martinez-Saldarriaga, J.; Torres-León, C.; Ascacio-Valdes, A.; Aguilar, C.N. Solid-state fermentation-Assisted extraction of bioactive compounds from hass avocado seeds. Food Bioprod. Process. 2021, 126, 155-163. [CrossRef]

15. Dulf, F.V.; Vodnar, D.C.; Socaciu, C. Effects of solid-state fermentation with two filamentous fungi on the total phenolic contents, flavonoids, antioxidant activities and lipid fractions of plum fruit (Prunus domestica L.) by-products. Food Chem. 2016, 209, 27-36. [CrossRef] [PubMed]

16. Dulf, F.V.; Vodnar, D.C.; Dulf, E.H.; Diaconeasa, Z.; Socaciu, C. Liberation and recovery of phenolic antioxidants and lipids in chokeberry (Aronia melanocarpa) pomace by solid-state bioprocessing using Aspergillus niger and Rhizopus oligosporus strains. LWT 2018, 87, 241-249. [CrossRef]

17. Zambrano, C.; Kotogán, A.; Bencsik, O.; Papp, T.; Vágvölgyi, C.; Mondal, K.C.; Krisch, J.; Takó, M. Mobilization of phenolic antioxidants from grape, apple and pitahaya residues via solid state fungal fermentation and carbohydrase treatment. LWT Food Sci. Technol. 2018, 89, 457-465. [CrossRef]

18. Dulf, F.V.; Vodnar, D.C.; Toşa, M.I.; Dulf, E.H. Simultaneous enrichment of grape pomace with $\gamma$-linolenic acid and carotenoids by solid-state fermentation with Zygomycetes fungi and antioxidant potential of the bioprocessed substrates. Food Chem. 2020, 310, 125927. [CrossRef]

19. Călinoiu, L.F.; Cătoi, A.F.; Vodnar, D.C. Solid-state yeast fermented wheat and oat bran as a route for delivery of antioxidants. Antioxidants 2019, 8, 372. [CrossRef]

20. Zhang, Y.; Liu, J.; Lu, X.; Zhang, H.; Wang, L.; Guo, X.; Qi, X.; Qian, H. Isolation and identification of an antioxidant peptide prepared from fermented peanut meal using Bacillus subtilis fermentation. Int. J. Food Prop. 2014, 17, 1237-1253. [CrossRef]

21. Sadh, P.K.; Chawla, P.; Duhan, J.S. Fermentation approach on phenolic, antioxidants and functional properties of peanut press cake. Food Biosci. 2018, 22, 113-120. [CrossRef]

22. Da Costa Maia, I.; Thomaz dos Santos D'Almeida, C.; Guimarães Freire, D.M.; D'Avila Costa Cavalcanti, E.; Cameron, L.C.; Furtado Dias, J.; Simões Larraz Ferreira, M. Effect of solid-state fermentation over the release of phenolic compounds from brewer's spent grain revealed by UPLC-MSE. LWT 2020, 133, 110136. [CrossRef]

23. Bangar, S.P.; Sandhu, K.S.; Purewal, S.S.; Kaur, M.; Kaur, P.; Siroha, A.K.; Kumari, K.; Singh, M.; Kumar, M. Fermented barley bran: An improvement in phenolic compounds and antioxidant properties. J. Food Process. Preserv. 2021, e15543. [CrossRef]

24. Mao, M.; Wang, P.; Shi, K.; Lu, Z.; Bie, X.; Zhao, H.; Zhang, C.; Lv, F. Effect of solid state fermentation by Enterococcus faecalis M2 on antioxidant and nutritional properties of wheat bran. J. Cereal Sci. 2020, 94, 102997. [CrossRef] 
25. Dei Piu', L.; Tassoni, A.; Serrazanetti, D.I.; Ferri, M.; Babini, E.; Tagliazucchi, D.; Gianotti, A. Exploitation of starch industry liquid by-product to produce bioactive peptides from rice hydrolyzed proteins. Food Chem. 2014, 155, 199-206. [CrossRef] [PubMed]

26. Alvarado Pérez, Y.; Muro Urista, C.; Maciel Cerda, A.; Álvarez Sánchez, J.; Riera Rodríguez, F. Antihypertensive and antioxidant properties from whey protein hydrolysates produced by encapsulated Bacillus subtilis cells. Int. J. Pept. Res. Ther. 2019, 25, 681-689. [CrossRef]

27. Rochín-Medina, J.J.; Ramírez-Medina, H.K.; Rangel-Peraza, J.G.; Pineda-Hidalgo, K.V.; Iribe-Arellano, P. Use of whey as a culture medium for Bacillus clausii for the production of protein hydrolysates with antimicrobial and antioxidant activity. Food Sci. Technol. Int. 2018, 24, 35-42. [CrossRef] [PubMed]

28. Gammoh, S.; Alu'datt, M.H.; Tranchant, C.C.; Al-U'datt, D.G.; Alhamad, M.N.; Rababah, T.; Kubow, S.; Haddadin, M.S.Y.; Ammari, Z.; Maghaydah, S.; et al. Modification of the functional and bioactive properties of camel milk casein and whey proteins by ultrasonication and fermentation with Lactobacillus delbrueckii subsp. lactis. LWT 2020, 129, 109501. [CrossRef]

29. Yu, H.C.; Hsu, J.L.; Chang, C.I.; Tan, F.J. Antioxidant properties of porcine liver proteins hydrolyzed using Monascus purpureus. Food Sci. Biotechnol. 2017, 26, 1217-1225. [CrossRef]

30. Jain, S.; Anal, A.K. Production and characterization of functional properties of protein hydrolysates from egg shell membranes by lactic acid bacteria fermentation. J. Food Sci. Technol. 2017, 54, 1062-1072. [CrossRef]

31. Martí-Quijal, F.J.; Tornos, A.; Príncep, A.; Luz, C.; Meca, G.; Tedeschi, P.; Ruiz, M.-J.; Barba, F.J. Impact of fermentation on the recovery of antioxidant bioactive compounds from sea bass byproducts. Antioxidants 2020, 9, 239. [CrossRef]

32. Fang, B.; Sun, J.; Dong, P.; Xue, C.; Mao, X. Conversion of turbot skin wastes into valuable functional substances with an eco-friendly fermentation technology. J. Clean. Prod. 2017, 156, 367-377. [CrossRef]

33. Ruthu., N.; Murthy, P.S.; Rai, A.K.; Bhaskar, N. Fermentative recovery of lipids and proteins from freshwater fish head waste with reference to antimicrobial and antioxidant properties of protein hydrolysate. J. Food Sci. Technol. 2014, 51, $1884-1892$. [CrossRef] [PubMed]

34. Choksawangkarn, W.; Phiphattananukoon, S.; Jaresitthikunchai, J.; Roytrakul, S. Antioxidative peptides from fish sauce byproduct: Isolation and characterization. Agric. Nat. Resour. 2018, 52, 460-466. [CrossRef]

35. Ismail, S.A. Microbial valorization of shrimp byproducts via the production of thermostable chitosanase and antioxidant chitooligosaccharides. Biocatal. Agric. Biotechnol. 2019, 20, 101269. [CrossRef]

36. Sachindra, N.M.; Bhaskar, N. In vitro antioxidant activity of liquor from fermented shrimp biowaste. Bioresour. Technol. 2008, 99, 9013-9016. [CrossRef] [PubMed]

37. Christ-Ribeiro, A.; Graça., C.S.; Kupski, L.; Badiale-Furlong, E.; De Souza-Soares, L.A. Cytotoxicity, antifungal and anti mycotoxins effects of phenolic compounds from fermented rice bran and Spirulina sp. Process Biochem. 2019, 80, 190-196. [CrossRef]

38. Denardi-Souza, T.; Luz, C.; Mañes, J.; Badiale-Furlong, E.; Meca, G. Antifungal effect of phenolic extract of fermented rice bran with Rhizopus oryzae and its potential use in loaf bread shelf life extension. J. Sci. Food Agric. 2018, 98, 5011-5018. [CrossRef] [PubMed]

39. Cantatore, V.; Filannino, P.; Gambacorta, G.; De Pasquale, I.; Pan, S.; Gobbetti, M.; Di Cagno, R. Lactic acid fermentation to re-cycle apple by-products for wheat bread fortification. Front. Microbiol. 2019, 10, 2574. [CrossRef] [PubMed]

40. Izzo, L.; Luz, C.; Ritieni, A.; Mañes, J.; Meca, G. Whey fermented by using Lactobacillus plantarum strains: A promising approach to increase the shelf life of pita bread. J. Dairy Sci. 2020, 103, 5906-5915. [CrossRef] [PubMed]

41. Luz, C.; Rodriguez, L.; Romano, R.; Mañes, J.; Meca, G. A natural strategy to improve the shelf life of the loaf bread against toxigenic fungi: The employment of fermented whey powder. Int. J. Dairy Technol. 2020, 73, 88-97. [CrossRef]

42. Martí-Quijal, F.J.; Príncep, A.; Tornos, A.; Luz, C.; Meca, G.; Tedeschi, P.; Ruiz, M.-J.; Barba, F.J.; Mañes, J. Isolation, Identification and investigation of fermentative bacteria from sea bass (Dicentrarchus labrax): Evaluation of antifungal activity of fermented fish meat and by-products broths. Foods 2020, 9, 576. [CrossRef]

43. Chang, W.T.; Chen, Y.C.; Jao, C.L. Antifungal activity and enhancement of plant growth by Bacillus cereus grown on shellfish chitin wastes. Bioresour. Technol. 2007, 98, 1224-1230. [CrossRef]

44. Thomas, L.; Larroche, C.; Pandey, A. Current developments in solid-state fermentation. Biochem. Eng. J. 2013, 81, 146-161. [CrossRef]

45. Behera, S.S.; Ray, R.C. Solid state fermentation for production of microbial cellulases: Recent advances and improvement strategies. Int. J. Biol. Macromol. 2016, 86, 656-669. [CrossRef] [PubMed]

46. Sadh, P.K.; Duhan, S.; Duhan, J.S. Agro-industrial wastes and their utilization using solid state fermentation: A review. Bioresour. Bioprocess. 2018, 1-15. [CrossRef]

47. Cerda, A.; Artola, A.; Barrena, R.; Font, X.; Gea, T.; Sánchez, A. Innovative production of bioproducts from organic waste through solid-state fermentation. Front. Sustain. Food Syst. 2019, 3, 63. [CrossRef]

48. Arte, E.; Rizzello, C.G.; Verni, M.; Nordlund, E.; Katina, K.; Coda, R. Impact of enzymatic and microbial bioprocessing on protein modification and nutritional properties of wheat bran. J. Agric. Food Chem. 2015, 63, 8685-8693. [CrossRef]

49. Fang, J.; Liu, Y.; Huan, C.C.; Xu, L.; Ji, G.; Yan, Z. Comparison of poly- $\gamma$-glutamic acid production between sterilized and non-sterilized solid-state fermentation using agricultural waste as substrates. J. Clean. Prod. 2020, 255, 120248. [CrossRef]

50. Teles, A.S.C.; Chávez, D.W.H.; Oliveira, R.A.; Bon, E.P.S.; Terzi, S.C.; Souza, E.F.; Gottschalk, L.M.F.; Tonon, R.V. Use of grape pomace for the production of hydrolytic enzymes by solid-state fermentation and recovery of its bioactive compounds. Food Res. Int. 2019, 120, 441-448. [CrossRef] 
51. Sharifi-Rad, M.; Anil Kumar, N.V.; Zucca, P.; Varoni, E.M.; Dini, L.; Panzarini, E.; Rajkovic, J.; Tsouh Fokou, P.V.; Azzini, E.; Peluso, I.; et al. Lifestyle, oxidative stress, and antioxidants: Back and forth in the pathophysiology of chronic diseases. Front. Physiol. 2020, 11, 694. [CrossRef] [PubMed]

52. Hassoun, A.; Carpena, M.; Prieto, M.A.; Simal-Gandara, J.; Özogul, F.; Özogul, Y.; Çoban, Ö.E.; Guðjónsdóttir, M.; Barba, F.J.; Marti-Quijal, F.J.; et al. Use of spectroscopic techniques to monitor changes in food quality during application of natural preservatives: A review. Antioxidants 2020, 9, 882. [CrossRef] [PubMed]

53. Xu, D.P.; Li, Y.; Meng, X.; Zhou, T.; Zhou, Y.; Zheng, J.; Zhang, J.J.; Li, H. Natural antioxidants in foods and medicinal plants: Extraction, assessment and resources. Int. J. Mol. Sci. 2017, 18, 96. [CrossRef]

54. Septembre-Malaterre, A.; Remize, F.; Poucheret, P. Fruits and vegetables, as a source of nutritional compounds and phytochemicals: Changes in bioactive compounds during lactic fermentation. Food Res. Int. 2018, 104, 86-99. [CrossRef]

55. Mapelli-Brahm, P.; Barba, F.J.; Remize, F.; Garcia, C.; Fessard, A.; Mousavi Khaneghah, A.; Sant'Ana, A.S.; Lorenzo, J.M.; Montesano, D.; Meléndez-Martínez, A.J. The impact of fermentation processes on the production, retention and bioavailability of carotenoids: An overview. Trends Food Sci. Technol. 2020, 99, 389-401. [CrossRef]

56. Roselló-Soto, E.; Garcia, C.; Fessard, A.; Barba, F.; Munekata, P.; Lorenzo, J.; Remize, F.; Roselló-Soto, E.; Garcia, C.; Fessard, A.; et al. Nutritional and microbiological quality of tiger nut tubers (Cyperus esculentus), derived plant-based and lactic fermented beverages. Fermentation 2019, 5, 3. [CrossRef]

57. Leonard, W.; Zhang, P.; Ying, D.; Adhikari, B.; Fang, Z. Fermentation transforms the phenolic profiles and bioactivities of plant-based foods. Biotechnol. Adv. 2021, 49, 107763. [CrossRef] [PubMed]

58. Loo, Y.T.; Howell, K.; Chan, M.; Zhang, P.; Ng, K. Modulation of the human gut microbiota by phenolics and phenolic fiber-rich foods. Compr. Rev. Food Sci. Food Saf. 2020, 19, 1268-1298. [CrossRef] [PubMed]

59. Verni, M.; Verardo, V.; Rizzello, C.G. How fermentation affects the antioxidant properties of cereals and legumes. Foods 2019, 8, 362. [CrossRef]

60. Embiriekah, S.; Bulatović, M.; Borić, M.; Zarić, D.; Arsić, S.; Rakin, M. Selection of Lactobacillus strains for improvement of antioxidant activity of different soy, whey and milk protein substrates. J. Hyg. Eng. Des. 2016, 16, 64-69.

61. Skrzypczak, K.; Gustaw, W.; Kononiuk, A.; Sołowiej, B.; Waśko, A. Estimation of the antioxidant properties of milk protein preparations hydrolyzed by Lactobacillus helveticus T80, T105 and B734. Czech J. Food Sci. 2019, 37, 260-267. [CrossRef]

62. García, C.; Rendueles, M.; Díaz, M. Synbiotic fermentation for the co-production of lactic and lactobionic acids from residual dairy whey. Biotechnol. Prog. 2017, 33, 1250-1256. [CrossRef]

63. Pescuma, M.; De Valdez, G.F.; Mozzi, F. Whey-derived valuable products obtained by microbial fermentation. Appl. Microbiol. Biotechnol. 2015, 99, 6183-6196. [CrossRef] [PubMed]

64. Guérin, M.; Silva, C.R.-D.; Garcia, C.; Remize, F. Lactic acid bacterial production of exopolysaccharides from fruit and vegetables and associated benefits. Fermentation 2020, 6, 115. [CrossRef]

65. Luo, J.; Huang, W.; Guo, W.; Ge, R.; Zhang, Q.; Fang, F.; Feng, Q.; Cao, J.; Wu, Y. Novel strategy to stimulate the food wastes anaerobic fermentation performance by eggshell wastes conditioning and the underlying mechanisms. Chem. Eng. J. 2020, 398, 125560. [CrossRef]

66. Tsai, W.T.; Yang, J.M.; Lai, C.W.; Cheng, Y.H.; Lin, C.C.; Yeh, C.W. Characterization and adsorption properties of eggshells and eggshell membrane. Bioresour. Technol. 2006, 97, 488-493. [CrossRef]

67. Marti-Quijal, F.J.; Remize, F.; Meca, G.; Ferrer, E.; Ruiz, M.-J.; Barba, F.J. Fermentation in fish and by-products processing: An overview of current research and future prospects. Curr. Opin. Food Sci. 2020, 31, 9-16. [CrossRef]

68. Leyva Salas, M.; Mounier, J.; Valence, F.; Coton, M.; Thierry, A.; Coton, E. Antifungal microbial agents for food biopreservation-A review. Microorganisms 2017, 5, 37. [CrossRef] 